\title{
ANALISIS KOMPARASI NILAI TAMBAH PRODUK OLAHAN NENAS PADA AGROINDUSTRI DI KABUPATEN MUARO JAMBI
}

\author{
Anita Hannum ${ }^{1}$, Yusma Damayanti ${ }^{2}$ dan Elwamendri ${ }^{2}$ \\ 1) Alumni Program Studi Agribisnis Fakultas Pertanian Universitas Jambi \\ 2) Staf Pengajar Program Studi Agribisnis Fakultas Pertanian Universitas Jambi \\ Email : anitahannumbatubara@yahoo.com
}

\begin{abstract}
ABSTRAK
Penelitian ini bertujuan untuk mengetahui gambaran agroindustri berbahan baku nenas di Kabupaten Muaro Jambi, untuk mengetahui besarnya nilai tambah yang diperoleh dari usaha pengolahan nenas menjadi dodol nenas, nenas goreng dan selai nenas di Kabupaten Muaro Jambi, untuk membandingkan nilai tambah yang diperoleh dari usaha pengolahan nenas menjadi dodol nenas, nenas goreng dan selai nenas di Kabupaten Muaro Jambi, dan untuk membandingkan nilai tambah yang diperoleh dari usaha pengolahan nenas pada setiap agroindustri yang terdapat di Kabupaten Muaro Jambi. Metode deskriptif digunakan untuk mengetahui gambaran umum agroindustri berbahan baku nenas, untuk menghitung nilai tambah digunakan metode Hayami dan untuk membandingkan nilai tambah digunakan uji statistik Analisis Varians Satu Arah (one way ANOVA). Hasil penelitian diperoleh besarannya nilai tambah yang diperoleh dari usaha pengolahan nenas menjadi selai nenas ialah sebesar Rp. 4.587,12, pengolahan nenas menjadi dodol nenas ialah sebesar Rp. 13.717,77 dan pengolahan nenas menjadi nenas goreng ialah sebesar Rp. 17.937,10. Persentase perbedaan nilai tambah yang dihasilkan dari pengolahan produk selai nenas dan dodol nenas adalah $65 \%$, perbedaan nilai tambah yang dihasilkan dari pengolahan produk dodol nenas dan nenas goreng adalah $27 \%$ sedangkan perbedaan nilai tambah yang dihasilkan dari pengolahan produk selai nenas dan nenas goreng adaalah 74\%. Persentase perbedaan nilai tambah yang dihasilkan dari pengolahan produk nenas goreng pada agroindustri "A" sebesar 14\%, "B" sebesar 14\%, "C" sebesar 16\%, "D" sebesar 15\%, "E" sebesar $19 \%$ dan "F" sebesar 23\%. Namun setelah dilakukan uji statistik analisis varians satu arah (one way ANOVA) perbedaan nilai tambah tidak nyata (signifakan).
\end{abstract}

Kata Kunci : Selai Nenas, Dodol Nenas, Nenas Goreng

\section{ABSTRACT}

The purpose of the research is to know the overiew of agroindustry raw material of pineapple at Muaro Jambi district, to know how added value that got from processing of pineapple become pineapple dodol, fried pineapple and pineapple jam at Muaro Jambi, to compare added value that got from processing of pineapple become pineapple dodol, fried pineapple and pineapple jam at Muaro Jambi, to compare added value that got from processing of pineapple on every agroindustry that found in Muara Jambi district. The method that used is descriptive method used to know the overiew of agroindustry raw material of pineapple, Hayami method used to count income and one way ANOVA is used to compare added value. The results of this research shows that amount of Rp. 4587.12 added value that got from processing of pineapples become pineapple jam, amount of Rp. 13717.77 processing of pineapples become pineapple dodol and around Rp. 17937.10 processing of pineapples become pineapple fried. The differentation of added value that got from processing pineapple jam and pineapple dodol product is $65 \%$. The differentation of added value that got processing pineapple dodol and fried pineapple product is $27 \%$. Whereas, distiction of added value that got from processing pineapple jam and fried pineapple product is $74 \%$. The differentation percentage of added value that got from processing fried pineapple product on agroindustry " $A$ " as many as $14 \%$, " $B$ " as many as $14 \%$, "C" as many as 16\%, " $D$ " as many as 15\%, "E" as many as $19 \%$ and " $F$ " as many as $23 \%$. However, after the statistical test one-way analysis of variance (one way ANOVA) difference no real added value (significant). 
Sektor pertanian dalam wawasan agribisnis dengan perannya dalam perekonomian nasional memberikan beberapa hal yang menunjukkan keunggulan yang dapat dipertimbangkan. Keunggulan tersebut antara lain nilai tambah pada agroindustri, misalnya dengan cara pengawetan produk pertanian menjadi produk olahan yang lebih tahan lama dan siap dikonsumsi. Mengingat sifat produk pertanian yang tidak tahan lama maka peran agroindustri sangat diperlukan (Azis,1993). Di Indonesia hampir seluruh komoditas pertanian dapat diolah, salah satunya adalah buah nenas. Nenas merupakan salah satu buah terpenting dari tiga buah lainnya yang berasal dari wilayah tropik (Aini, 2015). Provinsi Jambi khususnya Kabupaten Muaro Jambi mempunyai potensi pertanian yang dapat dikembangkan menjadi industri kecil yang sangat berdaya menggerakkan perekonomian rakyat. Perkebunan nenas yang cukup banyak dikelola rakyat menjadi sumber pendapatan yang cukup bernilai. Dengan sumberdaya yang dimiliki, daerah ini mempunyai potensi sebagai daerah pengembangan agroindustri produk olahan nenas.

Dengan adanya industri yang mengubah bentuk primer menjadi produk baru yang lebih tinggi nilai ekonomisnya setelah melalui proses pengolahan, maka akan dapat memberikan nilai tambah karena dikeluarkannya biaya-biaya sehingga terbentuk harga baru yang lebih tinggi dan keuntungannya lebih besar bila dibandingkan tanpa melalui proses pengolahan. Nilai tambah adalah pertambahan nilai suatu komoditi karena adanya input fungsional yang diberlakukan pada komoditi tersebut. Nilai tambah tersebut dapat diketahui melalui perhitungan dengan menggunakan metode tertentu (Suprapto, 2006). Pada perkembangannya dalam memproduksi olahan nenas terjadi dinamika permintaan pasar sehingga agroindustri memproduksi olahan nenas dalam berbagai jenis. Perkembangan ini mengalami penyesuaian terhadap konsumen. Kondisi yang dijelaskan oleh ketua pengolahan hasil panen dinas pertanian tanaman hortikutura Kabupaten Muaro Jambi dan pemilik agroindustri merupakan selera masyarakat yang menginginkan variasi jenis olahan nenas. Kebutuhan masyarakat inilah yang coba diakomodir oleh agroindustri. Hal ini dilakukan sebagai pemenuhan kebutuhan yang tidak terbatas oleh masyarakat selaku konsumen.

Dimana diketahui bahwa buah nenas dapat diolah sebagai manisan, dodol nenas, buah kaleng, selai nenas, nenas goreng, dan sebagainya. Namun pada agroindustri yang terdapat di Desa Tangkit Baru Kecamatan Sungai Gelam buah nenas diolah menjadi tiga jenis olahan yaitu, dodol nenas, nenas goreng dan selai nenas. Dari ketiga olahan tersebut akan memberikan nilai tambah yang berbeda dengan penggunaan input yang berbeda pula. Maka dari itu perlu strategi yang tepat dalam menggunakan input yang terbatas untuk menghasilkan produk yang memberikan keuntungan yang tinggi. Jika dikaitkan antara nilai tambah dan dinamika permintaan pasar, selanjutnya perlu dilakukan perhitungan nilai tambah masingmasing produk olahan nenas. Dalam hal ini hasil perhitungan nilai tambah produk dapat dijadikan acuan informasi bagi pihak agroindustri dalam mengembangkan usaha. Penelitian ini difokuskan pada perhitungan nilai tambah yang dihasilkan dodol nenas, nenas goreng dan selai nenas. Serta perhitungan nilai tambah nenas goreng yang dihasilkan pada setiap agroindustri yang berada di daerah penelitian. Hal ini dilakukan untuk mengetahui gambaran agroindustri berbahan baku nenas di Kabupaten Muaro Jambi, untuk mengetahui besarnya nilai tambah yang diperoleh dari usaha pengolahan nenas menjadi dodol nenas, nenas goreng dan selai nenas di Kabupaten Muaro Jambi, untuk mengetahui produk olahan mana yang menghasilkan nilai tambah yang lebih besar dan untuk membandingkan nilai tambah yang diperoleh dari usaha pengolahan nenas pada setiap agroindustri yang terdapat di Kabupaten Muaro Jambi. 


\section{METODE PENELITIAN}

Daerah penelitian ditentukan secara purposive atau sengaja, yaitu di Kabupaten Muaro Jambi. Alasan memilih Kabupaten Muaro Jambi adalah dengan pertimbangan bahwa Kabupaten Muaro Jambi merupakan satu-satunya daerah industri pengolahan nenas menjadi berbagai macam produk seperti dodol nenas, nenas goreng dan selai nenas yang terpusat di kecaamatan Sungai Gelam desa Tangkit Baru.

Penelitian ini mengunakan dua jenis data yaitu data primer dan data sekunder. Metode pengumpulan data primer yaitu dengan cara observasi dan wawancara. Observasi yaitu metode pengamatan dan peninjauan langsung ke objek penelitian. Wawancar yaitu dengan mengajukan pertanyaan-pertanyaan kepada pemilik agroindustri dan karyawannya untuk memperoleh informasi-informasi yang berkaitan denagn permasalahan yang akan diteliti dengan menggunakan kuisioner yang telah dipersiapkan.

Untuk identifikasi masalah (1) dianalisis dengan metode deskriptif, yaitu dengan menjelaskan keadaan umum agroindustri yang terdapat didaerah penelitian.Untuk menguji hipotesis (2) digunakan analisis nilai tambah metode Hayami. Untuk identifikasi masalah (2) dan (3) dianalisis dengan analisa varians satu arah (one way ANOVA).

\section{HASIL DAN PEMBAHASAN}

\section{Gambaran umum agroindustri berbahan baku nenas}

Sampai saat ini terdapat enam agroindustri berbahan baku nenas di Kabupaten Muaro Jambi. Lima diantaranya hanya mengolah nenas menjadi nenas goreng yaitu agroindustri dengan merk dagang Malakue, Masagena, Yusra, Jaya Indah, dan Bacode. Sedangkan satu agroindustri memproduksi nenas dengan tiga jenis produk yaitu dalam bentuk selai nenas, nenas goreng dan dodol nenas. Agroindustri ini merupakan agroindustri terbesar dan terlama di daerah ini. Agroindustri ini memiliki merk dagang Tulimario. Agroindustri ini dapat memproduksi nenas dengan tiga jenis olahan dikarenakan agroindustri ini telah memiliki pasar tetap dalam memasarkan selai dan dodol nenas olahannya. Jumlah Tenaga Kerja yang digunakan saat memproduksi produk olahan nenas berkisar antara tiga sampai sepuluh orang. Bahan baku yang digunakan untuk memproduksi olahan nenas ini diperoleh dari hasil panen petani sekitar desa tangkit baru. Nenas yang dibeli dari petani sekitar adalah nenas hasil sortiran dari pedagang pengumpul yang kualitasnya tidak termasuk dalam hitungan pedagang pengumpul. Sehingga harga belinya sangat jauh dari harga pasaran yaitu Rp. 1.000/kg sampai Rp. 2000/kg. Satu-satunya yang menjadi kendala dalam agroindustri ini adalah jangkauan pasar dari produk yang dihasilkan. Olahan nenas yang dihasilkan dari daerah ini baru menjangkau pasar dalam Provinsi Jambi itupun hanya pada Kabupaten Muaro Jambi dan Kota Jambi.

\section{Komponen Pembentuk Nilai Tambah}

Analisis nilai tambah mengidentifikasi bagaimana kekayaan perusahaan diciptakan melalui proses produksi dan bagaimana distribusi kekayaan dilakukan. Analisis nilai tambah berguna untuk menentukan faktor yang paling berjasa dalam meningkatkan nilai tambah dalam proses produksi. Analisis nilai tambah juga dapat dijadikan acuan mengalokasikan sumberdaya, perbaikan metode kerja, serta lebih mengefisienkan penggunaan masukan (input). Perhitungan nilai tambah metode Hayami dibagi menjadi tiga bagian yaitu output, input, dan harga; pendapatan dan keuntungan; serta balas jasa terhadap faktor produksi. Komponen pembentuk nilai tambah dalam metode Hayami adalah jumlah output yang 
dihasilkan dan harga output per kg, biaya bahan baku per kg, faktor konversi, serta besarnya sumbangan input lain (Sudiyono, 2004).

Komponen pembentuk nilai tambah adalah komponen-komponen dalam tabel bantu Hayami yang akan menyusun perhitungan nilai tambah.

a. Bahan Baku

Bahan baku merupakan bahan utama yang digunakan dalam proses produksi. Bahan baku dalam pengolahan selai nenas, nenas goreng dan dodol nenas adalah buah nenas jenis Queen dengan satuan kg. Berikut merupakan rata-rata jumlah bahan baku dan harga bahan baku per proses produksi pada agroindustri "A" di Kabupaten Muaro Jambi periode Maret sampai April 2016.

Tabel 1. Rata-rata Jumlah Bahan Baku dan Harga Bahan Baku Per Proses Produksi pada Agroindustri "A" periode Maret sampai April 2016

\begin{tabular}{llrrr}
\hline No. & \multicolumn{1}{c}{ Komponen } & Nilai selai nenas & Nilai dodol nenas & Nilai nenas goreng \\
\cline { 2 - 4 } 1 & Bahan Baku $(\mathrm{kg})$ & 100 & 70 & 60 \\
2 & Harga bahan baku $(\mathrm{Rp} / \mathrm{kg})$ & 1000 & 1000 & 1000 \\
\hline & Rata-rata pemakaian bahan baku nenas untuk selai nenas adalah & $100 \mathrm{~kg}$, untuk dodol
\end{tabular}
nenas $70 \mathrm{~kg}$ dan nenas goreng adalah sebesar $60 \mathrm{~kg}$. terlihat penggunaan bahan baku dalam mengolah selai nenas, dodol nenas dan nenas goreng terdapat perbedaan. Persentase penggunaan bahan baku untuk selai nenas sebesar 43,48\%, dodol nenas sebesar 30,43\% dan nenas goreng sebesar $26,09 \%$.

b. Output

Output dalam penelitian ini adalah produk yang dihasilkan oleh agroindustri " $A$ " yang berbentuk selai nenas, dodol nenas dan nenas goreng dengan satuan kg. berikut adalah ratarata output, bahan baku, faktor konversi, harga output dan nilai output per proses produksi pada agroindustri “A” periode Maret sampai April 2016.

Tabel 2. Rata-rata output, bahan baku, faktor konversi, harga output dan nilai output per proses produksi pada agroindustri “A” periode Maret sampai April 2016.

\begin{tabular}{llrrr}
\hline No. & \multicolumn{1}{c}{ Komponen } & Nilai selai nenas & Nilai dodol nenas & Nilai nenas goreng \\
\cline { 2 - 2 } 1 & Output $(\mathrm{kg})$ & 60 & 40 & 35 \\
2 & Faktor Konversi & 0,60 & 0,57 & 0,58 \\
3 & Harga Output $(\mathrm{Rp} / \mathrm{kg})$ & 15.000 & $40.000,00$ & $50.000,00$ \\
4 & Nilai Output $(\mathrm{Rp} / \mathrm{kg})$ & 9.000 & $22.857,14$ & $29.166,67$ \\
\hline
\end{tabular}

Rata-rata faktor konversi hasil produksi terhadap pemakain bahan baku pada periode Maret sampai April 2016 adalah sebesar 0,60 pada selai nenas, 0,57 pada dodol nenas dan 0,58 pada nenas goreng yang artinya setiap penggunaan bahan baku $1 \mathrm{~kg}$ buah nenas setelah mengalami pengolahan akan menjadi $0,60 \mathrm{~kg}$ selai nenas; 0,57 pada dodol nenas yng artinya setiap penggunaan bahan baku $1 \mathrm{~kg}$ buah nenas setelah mengalami pengolahan akan menjadi $0,57 \mathrm{~kg}$ dodol nenas dan 0,58 nenas goreng setiap penggunaan bahan baku $1 \mathrm{~kg}$ buah nenas setelah mengalami pengolahan akan menjadi $0,58 \mathrm{~kg}$ nenas goreng.

Rata-rata harga output untuk selai nenas adalah Rp. 15.000/kg, dodol nenas Rp. $40.000 / \mathrm{kg}$ dan nenas goreng Rp. 50.000/kg. rata-rata nilai output yang dihasilkan selai nenas adalah Rp. 9.000; dodol nenas Rp. 22.857,14 dan nenas goreng Rp. 29.166,67. Artinya dari 1 $\mathrm{kg}$ buah nenas, mampu menghasilkan 0,60 kg selai nenas akan bernilai Rp. 9.000; dari $1 \mathrm{~kg}$ 
buah nenas, mampu menghasilkan $0,57 \mathrm{~kg}$ dodol nenas akan bernilai Rp. 22.857,14 dan dari $1 \mathrm{~kg}$ buah nenas, mampu menghasilkan 0,58 kg nenas goreng akan bernilai Rp. 29.166,67.

c. Sumbangan Input Lain

Sumbangan input lain terdiri dari biaya bahan penolong dan biayaa penyusutan alat per bahan baku. Alat diantaranya mesin parut, mesin pengaduk, mesin spiner, timbangan, kuali, mixer, loyang, tungku, kompor, tabung gas, baskom, saringan goreng, sendok goreng, pisau dan korek. Bahan penolong diantaranya gula, tepung terigu, minyak goreng, mentega, garam, kayu bakar, plastik kemasan, kotak kemasan, merk dagang dan tenaga listrik.

Dalam penelitian ini sumbangan input lain per proses produksi untuk setiap produk yang dihasilkan berbeda. Untuk proses produksi selai nenas sumbangan input lain yang dihasilkan adalah Rp. 3.412,88. Untuk proses produksi dodol nenas sumbangan input lain yang dihasilkan adalah Rp. 8.139,37. Untuk proses produksi nenas goreng sumbangan input lain yang dihasilkan adalah Rp. 10.229,57.

\section{Komponen Diluar Pembentuk Nilai Tambah}

Komponen diluar pembentuk nilai tambah adalah komponen-komponen dalam tabel Hayami tidak langsung menyusun perhitungan nilai tambah. Komponen diluar pembentuk nilai tambah terdiri dari jumlah tenaga kerja, koefisien tenaga kerja, upah rata-rata tenaga kerja. Penjelasan mengenai komponen diluar pembentuk nilai tambah akan dijelaskan dalam dua bagian yaitu tenaga kerja dan imbalan tenaga kerja (Sudiyono, 2004).

a. Tenaga Kerja

Tenaga kerja adalah tenaga kerja manusia yang melakukan proses produksi. Tenaga kerga ini merupakan tenaga kerja yang dikerahkan untuk mengolah bahan baku nenas menjadi selai nenas, dodol nenas dan nenas goreng dihitung dalam satu kali proses produksi. Tenaga kerja dihitung dalam satuan jam tenaga kerja menggunakan perhitungan upah per setiap tahap pengolahan pada agroindustri "A" periode Maret sampai April 2016. Secara lebih jelas dapat dilihat pada Tabel 3 berikut.

Tabel 3. Rata-rata Tenaga Kerja, Koefisien Tenaga Kerja, dan Upah rata-rata Tenaga Kerja Per Proses Produksi pada agroindustri "A" periode Maret sampai April 2016

\begin{tabular}{llrrr}
\hline No. & \multicolumn{1}{c}{ Komponen } & $\begin{array}{c}\text { Nilai selai } \\
\text { nenas }\end{array}$ & $\begin{array}{c}\text { Nilai dodol } \\
\text { nenas }\end{array}$ & \multicolumn{2}{c}{$\begin{array}{c}\text { Nilai nenas } \\
\text { goreng }\end{array}$} \\
\hline 1 & Tenaga kerja (jam kerja/proses produksi) & 5 & 6 & 8 \\
2 & Koefisien Tenaga Kerja & 0,050 & 0,086 & 0,133 \\
3 & Upah Tenaga kerja (Rp/proses produksi) & 35.000 & $60.000,00$ & $40.000,00$ \\
\hline
\end{tabular}

Rata-rata tenaga kerja bekerja pada satu proses produksi adalah sebesar 5 jam untuk produksi selai nenas, 6 jam untuk produksi dodol nenas dan 8 jam untuk produksi nenas goreng. Rata-rata koefisien tenaga kerja pada produksi selai nenas adalah sebesar 0,050 yang berarti untuk mengolah $100 \mathrm{~kg}$ bahan baku nenas menjadi selai nenas diperluan curahan tenaga kerja sebesar 5 jam, rata-rata koefisien tenaga kerja pada produksi dodol nenas adalah sebesar 0,086 yang berarti untuk mengolah $100 \mathrm{~kg}$ baahaan baku nenas menjdaaai selaai nenas diperluan curahan tenaga kerja sebesar 8,6 jam atau 8 jam 36 menit, sedangkan ratarata koefisien tenaga kerja pada produksi nenas goreng adalah sebesar 0,133 yang berarti untuk mengolah $100 \mathrm{~kg}$ baahaan baku nenas menjdaaai selaai nenas diperluan curahan tenaga kerja sebesar 13,3 jam atau 13 jam 18 menit.

b. Imbalan Tenaga Kerja

Imbalan tenaga kerja adalah rupiah yang didapat oleh tenaga kerja dari pengolaahan bahan baaku per proses produksinya. Rata-rata imblan tenaga kerja per produksi pada 
pengolahan selai nenas adalah Rp. 1.750; rata-rata imbalan tenaga kerja per produksi pada pengolahan dodol nenas adalah Rp. 5.142,86 dan rata-rata imbalan tenaga kerja per produksi pada pengolahan nenas goreng adalah $\mathrm{Rp}$. 5.333,33. Jika dibandingkan dengan penelitin Wulandari (2015) maka rata-rata imbalan tenaga kerja per produksi pada pengolahan nenas di agroindustri "A" cendrung lebih besar.

\section{Perhitungan nilai tambah metode Hayami}

Analisis nilai tambah mengidentifikasi bagaimana kekayaan perusahaan diciptakan melalui proses produksi dan bagaimana distribusi kekayaan dilakukan. Analisis nilai tambah berguna untuk menentukan faktor yang paling berjasa dalam meningkatkan nilai tambah dalam proses produksi. Analisis nilai tambah juga dapat dijadikan acuan mengalokasikan sumberdaya, perbaikan metode kerja, serta lebih mengefisienkan penggunaan masukan (input). Dalam proses pengolahan nilai tambah dapat didefenisikan sebagai selisih antara nilai produk dengan nilai biaya bahan baku dan input lainnya, tidak termasuk tenaga kerja. Sedangkan marjin adalah selisih antara nilai produk dengan nilai bahan bakunya saja. Dalam marjin ini tercakup komponen faktor produksi yang digunakan yaitu tenaga kerja, input lainnya dan balas jasa pengusaha pengolahan (Sudiyono, 2006)

Tabel 4. Perhitungan Nilai Tambah Rata-Rata Per Proses Produksi Menggunakan Metode Hayami Pada Agroindustri “A” Periode Maret Sampai April 2016

\begin{tabular}{|c|c|c|c|c|}
\hline No & Variabel & $\begin{array}{l}\text { Nilai selai } \\
\text { nenas }\end{array}$ & $\begin{array}{l}\text { Nilai dodol } \\
\text { nenas }\end{array}$ & $\begin{array}{l}\text { Nilai nenas } \\
\text { goreng }\end{array}$ \\
\hline \multirow[t]{8}{*}{ I. } & Output, Input dan Harga & & & \\
\hline & 1. Output $(\mathrm{kg})$ & 60 & 40 & 35 \\
\hline & 2. Input $(\mathrm{kg})$ & 100 & 70 & 60 \\
\hline & 3. Tenaga kerja $(\mathrm{HOK})$ & 5 & 6 & 8 \\
\hline & 4. Faktor Konversi & 0,60 & 0,57 & 0,58 \\
\hline & 5. Koefisien Tenaga Kerja & 0,050 & 0,086 & 0,133 \\
\hline & 6. Harga output $(\mathrm{Rp} / \mathrm{kg})$ & $15.000,00$ & $40.000,00$ & $50.000,00$ \\
\hline & 7. Upah Tenaga kerja (Rp/HOK) & $35.000,00$ & $60.000,00$ & $40.000,00$ \\
\hline \multirow[t]{10}{*}{ II. } & Penerimaan dan Keuntungan & & & \\
\hline & 8. Harga bahan baku $(\mathrm{Rp} / \mathrm{kg})$ & $1.000,00$ & $1.000,00$ & $1.000,00$ \\
\hline & 9. Sumbangan input lain $(\mathrm{Rp} / \mathrm{kg})$ & $3.412,88$ & $8.139,37$ & $10.229,57$ \\
\hline & 10. Nilai Output $(\mathrm{Rp} / \mathrm{kg})$ & $9.000,00$ & $22.857,14$ & $29.166,67$ \\
\hline & 11. a. Nilai Tambah $(\mathrm{Rp} / \mathrm{kg})$ & $4.587,12$ & $13.717,77$ & $17.937,10$ \\
\hline & b. Rasio Nilai Tambah (\%) & 50,97 & 60,02 & 61,50 \\
\hline & 12. a Pendapatan tenaga kerja $(\mathrm{Rp} / \mathrm{kg})$ & $1.750,00$ & $5.142,86$ & $5.333,33$ \\
\hline & b. Pangsa Tenaga kerja (\%) & 38,15 & 37,49 & 29,73 \\
\hline & 13. a. Keuntungan $(\mathrm{Rp} / \mathrm{kg})$ & $2.837,12$ & $8.574,92$ & $12.603,76$ \\
\hline & b Tingkat keuntungan $(\%)$ & 61,85 & 62,51 & 70,27 \\
\hline \multirow[t]{5}{*}{ III. } & Balas Jasa Pemilik Faktor Produksi & & & \\
\hline & 14. Marjin $(\mathrm{Rp} / \mathrm{Kg})$ & $8.000,00$ & $21.857,14$ & $28.166,67$ \\
\hline & Pendapatan Tenaga Kerja (\%) & 22 & 24 & 19 \\
\hline & Sumbangan Input Lain (\%) & 43 & 37 & 36 \\
\hline & Keuntungan Pengusaha (\%) & 35 & 39 & 45 \\
\hline
\end{tabular}

Nilai tambah yang diperoleh berasal dari proses pengolahan buah nenas sampai menjadi produk olahan. Analisis nilai tambah yang dilakukan dihasilkan dari perhitungan 
nilai output, harga bahan baku dan sumbangan input lain. Output (produk olahan) yang dihasilkan dalam pada proses ini adalah selai nenas, dodol nenas dan nenas goreng. Secara umum hasil perhitungan nilai tambah yang didapat, telah dianalisis untuk menunjukkan kekayaan agroindustri melalui proses produksi dan proses pendistribusian kekayaan dilakukan. Dari analisis nilai tambah yang dilakukan, telah ditentukan faktor yang berjasa dalam meningkatkan nilai tambah dalam proses produksi.

Ketiga komponen pembentuk nilai tambah yaitu nilai output, sumbangan input lain, dan harga bahan baku merupakan faktor yang berjasa dalam meningkatkan nilai tambah produksi. Dalam perhitungan nilai tambah pada agroindustri "A", harga bahan baku yang digunakan relatif kecil. Nilai output yang dihasilkan dikatakan cukup, penggunaan sumbangan input lain dan harga bahan baku yang relatif kecil pun menyebabkan nilai tambah yang dihasilkan cukup tinggi.

Berdasarkan Tabel 4 terlihat bahwa rata-rata nilai tambah yang dihasilkan agroindustri “A” periode Maret-April 2016 yaitu sebesar Rp. 4.587,12 untuk selai nenas, Rp. 13.717,77 untuk dodol nenas dan Rp. 17.937,10 untuk nenas goreng dengan rasio nilai tambah sebesar $50,97 \%$ untuk selai nenas, $60,02 \%$ untuk dodol nenas dan $61,50 \%$ untuk nenas goreng. Artinya setiap $1 \mathrm{~kg}$ bahan baku buah nenas dapat memberikan nilai tambah sebesar Rp. $4.587,12$ bila diolah menjadi selai nenas, Rp. 13.717,77 bila diolah menjadi dodol nenas dan Rp. 17.937,10bila diolah menjadi nenas goreng.

Nilai tambah tersebut merupakan nilai tambah yang belum dikurangi imbalan tenaga kerja.Rara-rata keuntungan (nilai tambah dikurangi imbalan tenaga kerja) yang dihasilkan selai nenas adalah Rp. 2.837,12 dengan persentase tingkat keuntungan sebesar $61,85 \%$, rararata keuntungan yang dihasilkan dodol nenas $\mathrm{Rp}$. 8.574,92 dengan persentase $62,51 \%$ dan rara-rata keuntungan yang dihasilkan nenas goreng Rp. 10.203,76 dengan persentase $56,89 \% .5$. Persentase perbedaan keuntungan yang dihasilkan selai nenas dan dodol nenas adalah $67 \%$, persentase perbedaan keuntungan yang dihasilkan dodol nenas dan nenas goreng adalah $32 \%$, sedangkan persentase perbedaan keuntungan yang dihasilkan selai nenas dan nenas goreng adalah $77 \%$.

Keuntungan rata-rata produksi selai nenas adalah Rp. 2.837,12 merupakan keuntungan untuk setiap kilogram bahan baku yang diolah. Maka pada penggunaan bahan baku rata-rata $100 \mathrm{~kg}$ dalam satu bulan didapat keuntungan sebesar Rp. 283.712 pada produksi pada selai nenas. Keuntungan rata-rata produksi dodol nenas adalah Rp. 8.574,92 merupakan keuntungan untuk setiap kilogram bahan baku yang diolah. Maka pada penggunaan bahan baku rata-rata $70 \mathrm{~kg}$ dalam satu bulan didapat keuntungan sebesar Rp. 600.244,40 pada produksi pada dodol nenas. Keuntungan rata-rata produksi nenas goreng adalah Rp. 10.203,76 merupakan keuntungan untuk setiap kilogram bahan baku yang diolah. Maka pada penggunaan bahan baku rata-rata $60 \mathrm{~kg}$ dalam satu bulan didapat keuntungan sebesar Rp. 612.225,60 pada produksi pada nenas goreng. Besaran marjin rata-rata per proses produksi untuk pengolahan selai nenas adalah sebesar Rp.8.000 / $\mathrm{kg}$ bahan baku yang terdiri atas pendapatan tenaga kerja sebesar $22 \%$, sumbangan input lain sebesar $43 \%$ dan keuntungan agroindustri sebesar 35\%. Artinya bila marjin Rp. 100/kg bahan baku maka Rp. 22 merupakan pendapatan tenaga kerja, Rp. 43 merupakan sumbangan input lain, dan Rp. 35 merupakan bagian untuk keuntungan agroindustri.

Besaran marjin rata-rata per proses produksi untuk pengolahan dodol nenas adalah sebesar Rp. $21.857,14 / \mathrm{kg}$ bahan baku yang terdiri atas pendapatan tenaga kerja sebesar $24 \%$, sumbangan input lain sebesar $37 \%$ dan keuntungan agroindustri sebesar $39 \%$. Artinya bila marjin Rp. 100/kg bahan baku maka Rp. 24 merupakan pendapatan tenaga kerja, Rp. 37 merupakan sumbangan input lain, dan Rp. 39 merupakan bagian untuk keuntungan agroindustri. Besaran marjin rata-rata per proses produksi untuk pengolahan nenas goreng 
adalah sebesar Rp. $28.166,67 / \mathrm{kg}$ bahan baku yang terdiri atas pendapatan tenaga kerja sebesar 27\%, sumbangan input lain sebesar 36\% dan keuntungan agroindustri sebesar 36\%. Artinya bila marjin Rp. 100/kg bahan baku maka Rp.27 merupakan pendapatan tenaga kerja, Rp. 36 merupakan sumbangan input lain, dan Rp. 36 merupakan bagian untuk keuntungan agroindustri.

\section{Analisis Rasio-Rasio Nilai Tambah dan Produktivitas}

Rasio nilai tambaha merupakan persentase nilai tambah dari produk. Menurut Suprapto (2006) rasio nilai tambah digunakan untuk mengukur kemajuan yang dicapai dalam bidang produktivitas suatu agroindusri yang menyangkut nilai tambah produktivitasnya. Rasio-rasio nilai tambah diperoleh dari komponen pembentuk nilai tambah pada perhitungan Hayami. Perhitungan rasio-rasio nilai tambah untuk setiap proses produksinya dihitung pada agroindustri "A" periode Maret sampai April 2016. Perhitungan rata-rata rasio-rasio nilai tambah untuk setiap proses produksinya dihitung pada agroindustri "A" periode Maret sampai April 2016 dapat dilihat pada Tabel 5. Dari hasil perhitungan rata-rata rasio-rasio selanjutnya akan digunakan untuk analisis produktivitas.

Tabel 5. Perhitungan Rata-rata Rasio-rasio Nilai Tambah pada Agroindustri "A" periode Maret sampai April 2016

\begin{tabular}{lrrr}
\hline \multirow{2}{*}{ Komponen } & \multicolumn{3}{c}{ Rata-rata } \\
\cline { 2 - 4 } & \multicolumn{1}{c}{ Selai } & Dodol & Goreng \\
\hline Rasio Nilai Tambah / Tenaga Kerja (Rp/TK) & 917,42 & $2.286,3$ & $2.242,14$ \\
Rasio Nilai Tambah / Output (\%) & 51 & 60 & 61 \\
Rasio Nilai Tambah / Biaya Tenaga Kerja (Rp) & 0,13 & 0,23 & 0,45 \\
Rasio Keuntungan / Nilai Tambah(\%) & 61,85 & 62,51 & 70,72 \\
\hline
\end{tabular}

\section{Analisis Rasio-rasio per Tenaga Kerja (Rp/Tk)}

a. Rasio Nilai Tambah / Tenaga Kerja (Rp/TK)

Rasio nilai tambah per tenaga kerja adalah rasio yang mencerminkan jumlah kekayaan yang diciptakan agroindustri relatif terhadap jumlah tenaga kerja yang ada. Dengan kata lain rasio ini mencerminkan banyaknya kekayaan yang dapat tercipta per kilogram bahan baku dengan menggunakan tenga kerja yang tersedia. Dari Tabel 5 terlihat hasil perhitungan ratarata rasio Rp. 917,42/TK untuk selai nenas berarti setiap penggunaan satu orang tenaga kerja akan memberikan nilai tambah sebesar Rp. 917,42. Hasil perhitungan rata-rata rasio Rp. 2.286,3/TK untuk dodol nenas berarti setiap penggunaan satu orang tenaga kerja akan memberikan nilai tambah sebesar $\mathrm{Rp}$. 2.286,3. Hasil perhitungan rata-rata rasio $\mathrm{Rp}$. 2.242,14/TK untuk dodol nenas berarti setiap penggunaan satu orang tenaga kerja akan memberikan nilai tambah sebesar Rp. 2.242,14.

b. Rasio Nilai Tambah / Output (\%)

Rasio nilai tambah per output adalah rasio yang mencerminkan tingkat keefisienan antara biaya produksi dengan nilai output. Dari Tabel 5 terlihat hasil perhitungan rata-rata rasio $51 \%$ pada selai nenas berarti dari setiap rupiah nilai output akan memberikan nilai tambah sebesar $51 \%$, perhitungan rata-rata rasio $60 \%$ pada dodol nenas berarti dari setiap rupiah nilai output akan memberikan nilai tambah sebesar $60 \%$ dan perhitungan rata-rata rasio $61 \%$ pada nenas goreng berarti dari setiap rupiah nilai output akan memberikan nilai tambah sebesar $61 \%$.

c. Rasio Nilai Tambah / Biaya Tenaga Kerja (Rp) 
Rasio nilai tambah per biaya tenaga kerja adalah rasio yang mencerminkan tingkat kemampuan agroindustri untuk menghasilkan kekayaan dari sejumlah upah yang dibayarkan kepada banyaknya tenaga kerja. Dengan kata lain rasio ini mencerminkan besarnya nilai tambah yang dapat diperoleh agroindustri dari jumlah biaya tenaga kerja yang dikeluarkan. Dari Tabel 5 terlihat hasil perhitungan rata-rata rasio Rp. 0,13 pada selai nenas berarti dari setiap rupiah yang dikeluarkan agroindustri untuk membayar tenaga kerja akan menghasilkan nilai tambah sebesar Rp. 0,13; hasil perhitungan rata-rata rasio Rp. 0,23 pada dodol nenas berarti dari setiap rupiah yang dikeluarkan agroindustri untuk membayar tenaga kerja akan menghasilkan nilai tambah sebesar Rp. 0,23 dan hasil perhitungan rata-rata rasio Rp. 0,45 pada nenas goreng berarti dari setiap rupiah yang dikeluarkan agroindustri untuk membayar tenaga kerja akan menghasilkan nilai tambah sebesar Rp. 0,45

d. Rasio Keuntungan / Nilai Tambah(\%)

Rasio keuntungan per nilai tambah adalah rasio mencerminkan besarnya keuntungan yang diperoleh sebagai bagian dari nilai tambah produksi. Dari Tabel 5 terlihat hasil perhitungan rata-rata rasio $61,85 \%$ pada selai nenas berarti agroindustri " $A$ " dapat menghasilkan keuntungan sebesar $61,85 \%$ dari setiap rupiah nilai tambah yang diperoleh agroindustri. Hasil perhitungan rata-rata rasio $62,51 \%$ pada dodol nenas berarti agroindustri "A" dapat menghasilkan keuntungan sebesar $62,51 \%$ dari setiap rupiah nilai tambah yang diperoleh agroindustri dan hasil perhitungan rata-rata rasio $70,72 \%$ pada nenas goreng berarti agroindustri "A" dapat menghasilkan keuntungan sebesar $70,72 \%$ dari setiap rupiah nilai tambah yang diperoleh agroindustri.

\section{Analisis Produktivitas}

a. Analisis Produktivitas Nilai Tambah / Tenaga Kerja (Rp/TK)

Produktivitas tambah per tenaga kerja merupakan kunci dalam pengukuran produktivitas. Rasio ini mencerminkan efisiensi dari tenaga kerja dalam menghasilkan output. Semakin besar rasio nilai tambah per tenaga kerja, berarti lebih banyak keuntungan yang dihasilkan dari kemampuan agroindustri dengan menggunakan tenaga kerja yang tersedia. Jika dihubungkan dengan produktivitas, berarti kemampuan tenaga kerja untuk menghasilkan kekayaan agroindustri semakin meningkat. Begitu juga sebaliknya, apabila rasio nilai tambah per tenaga kerja semakin kecil, artinya jumlah tenaga kerja atau prosedur kerja yang digunakan kurang menguntungkan agroindustri.

Dari Tabel 5 terlihat hasil perhitungan rata-rata rasio Rp. 917,42/TK menunjukkan bahwa periode Maret sampai April 2016, setiap tenaga kerja yang mengolah selai nenas mampu memberikan kekayaan bagi agroindustri sebesar Rp. 917,42. Hasil perhitungan ratarata rasio Rp. 2.286,30/TK menunjukkan bahwa periode Maret sampai April 2016, setiap tenaga kerja yang mengolah dodol nenas mampu memberikan kekayaan bagi agroindustri sebesar Rp. 2.286,30. Hasil perhitungan rata-rata rasio Rp. 2.242,14/TK menunjukkan bahwa periode Maret sampai April 2016, setiap tenaga kerja yang mengolah nenas goreng mampu memberikan kekayaan bagi agroindustri sebesar Rp. 2.242,14.

b. Analis Produktivitas Nilai Tambah / Output (\%)

Produktivitas nilai tambah per output adalah ukuran keefisienan penggunaan biaya produksi dari nilai tambah produk yang dihasilkan. Dari Tabel 5 terlihat hasil perhitungan rata-rata rasio $51 \%$ pada selai nenas, hasil perhitungan rata-rata rasio $60 \%$ pada dodol nenas dan hasil perhitungan rata-rata rasio $61 \%$ pada nenas goreng. Dari perolehan rasio nilai tambah per nilai output, dapat dikatakan baahwa penggunaan biaya produksi sudah efisien karena sudah melebihi 50\%.

Jika dihubungkan dengan produktivitas, dimana rasio nilai tambah per output pada selai nenas sebesar $51 \%$ artinya penggunaan biaya produksi sudah efisien karena telah mmpu 
menghsilkan nilai tambah sebesar $51 \%$, rasio nilai tambah per output pada dodol nenas sebesar $60 \%$ artinya penggunaan biaya produksi sudh efisien arenaa telah mmpu menghsilkan nilai tambah sebesar $60 \%$ dan rasio nilai tambah per output pada nenas goreng sebesar $61 \%$ artinya penggunaan biaya produksi sudah efisien karena telah mmpu menghsilkan nilai tambah sebesar $61 \%$.

c. Analisis Produktivitas Nilai Tambah / Biaya Tenaga Kerja (Rp)

Produktivitas nilai tambah per biaya tenaga kerja mencerminkan keefisienan upah yang dibayarkan ke tenaga kerja dari nilai tambah produk yang dihasilkan. Dari Tabel 5 terlihat hasil perhitungan rata-rata rasio Rp. 0,13 pada selai nenas, hasil perhitungan rata-rata rasio Rp. 0,23 pada dodol nenas dan hasil perhitungan rata-rata rasio Rp. 0,31 pada nenas goreng. Jika dihubungkan dengan produktivitas, dimana rasio nilai tambah per biaya tenaga kerja pada selai nenas Rp. 0,13 artinya untuk setiap rupiah yang dikeluarkan agroindustri untuk biaya tenaga kerja maka nilai tambah yang diterima sebesar $0,13 \%$, rasio nilai tambah per biaya tenaga kerja pada dodol nenas Rp. 0,23 artinya untuk setiap rupiah yang dikeluarkan agroindustri untuk biaya tenaga kerja maka nilai tambah yang diterima sebesar $0,23 \%$ dan rasio nilai tambah per biaya tenaga kerja pada nenas goreng Rp. 0,45 artinya untuk setiap rupiah yang dikeluarkan agroindustri untuk biaya tenaga kerja maka nilai tambah yang diterima sebesar $0,45 \%$.

d. Analis Produktivitas Keuntungan / Nilai Tambah(\%)

Besarnya keuntungan yang diperoleh dari pengolahan sumber daya nenas menjadi olahan nenas ditunjukkan oleh produktivitas keuntungan per nilai tambah. Dari Tabel 5 terlihat hasil perhitungan rata-rata rasio $61,85 \%$ pada selai nenas, hasil perhitungan rata-rata rasio $62,51 \%$ pada dodol nenas dan hasil perhitungan rata-rata rasio $56,89 \%$ pada nenas goreng. Jika dihubungkan dengan produktivitas dan dianggap ukuran produktivitas tertinggi $100 \%$ maka artinya produktivitas keuntungn per nilai tambah cukup tinggi. Rata-rata rasio keuntungan per nilai tambah pada selai nenas sebesar $61,85 \%$ artinya untuk setiap rupiah nilai tambah yang diperoleh maka agroindustri mendapat keuntungan sebesar $61,85 \%$ dari tiap proses produksinya, rata-rata rasio keuntungan per nilai tambah pada dodol nenas sebesar $62,51 \%$ artinya untuk setiap rupiah nilai tambah yang diperoleh maka agroindustri mendapat keuntungan sebesar $62,51 \%$ dari tiap proses produksinya dan rata-rata rasio keuntungan per nilai tambah pada nenas goreng sebesar $70,72 \%$ artinya untuk setiap rupiah nilai tambah yang diperoleh maka agroindustri mendapat keuntungan sebesar $70,72 \%$ dari tiap proses produksinya.

\section{Komparasi Nilai Tambah Antar Produk Olahan}

Analisis komparasi nilai tambah antar produk olahan dilakukan dengan pengujian hipotesis perbandingan nilai tambah. Hasil perhitungan nilai tambah rata-rata pada selai nenas adalah sebesar Rp. 4.587,12; nilai tambah dodol nenas sebesar Rp. 13.7117,77 dan nilai tambah nenas goreng sebesar Rp. 17.937,10. Tabel hasil uji anova dengan SPSS, diperoleh $\mathrm{dk}$ antar kelompok (pembanding) $=2$, dk dalam kelompok (penyebut) $=9$, pada alfa $=0.05$ maka nilai $F$ tabelnya adalah 19,38 . Sedang $F$ hitung $=1,431$. Nilai Fhitung < Ftabel. Maka H0 diterima pada taraf nyata 0,05 (H1 ditolak). Kesimpulannya, pada tiga jenis produk olahan yang diuji memiliki perbedaan nilai tambah yang nyata (signifikan) dalam nilai AUC.

\section{Komparasi Nilai Tambah Antar Agroindustri}

Komparasi nilai tambah antar agroindustri yang menghasilkan nenas goreng dilakukan dengan pengujian hipotesis perbandingan nilai tambah. Hasil perhitungan nilai tambah rata- 
rata nilai tambah nenas goreng pada agroindustri di dearah penelitian berdasarkan perhitungan nilai tambah metode Hayami yaitu sebesar Rp. 17.937,10 pada agroindustri "A", Rp. 21.226,12 pada agroindustri "B”, Rp. 20.393,35 pada agroindustri "C", Rp. 18.892,57 pada agroindustri "D", Rp. 21.291,01 pada agroindustri "E" dan Rp. 18.218,24 pada agroindustri "F". Tabel hasil uji anova AUC dengan SPSS, diperoleh dk antar kelompok (pembanding) $=5$, dk dalam kelompok (penyebut) $=18$, pada alfa $=0,05$ maka nilai $\mathrm{F}$ tabelnya adalah 2,77. Sedang F hitung $=4,008$. Nilai Fhitung $>$ Ftabel. Maka H0 ditolak pada taraf nyata 0,05 (H1 diterima). Kesimpulannya, pada keenam agroindustri berbahan baku nenas yang terdapat di daerah penelitian yang diuji memiliki perbedaan nilai tambah yang tidak nyata (signifikan) dalam nilai AUC.

\section{KESIMPULAN}

Agroindustri berbahan baku nenas yang terdapat di Kabupaten Muaro Jambi mulai berdiri dari tahun 1991 dan hanya terdapat satu agroindustri pada masa itu. Pada awal keberadaannya agroindustri ini hanya menghasilkan satu produk olahan yaitu dodol nenas. Seiring dengan berjalannya waktu agroindustri serupa mulai bermunculan dengan produk unggulannya nenas goreng, hingga saat ini terdapat 5 agroindustri penghasil nenas goreng dan satu agroindustri penghasil nenas goreng, selai nenas dan dodol nenas di Kabupaten Muaro Jambi. Hasil pengujian secara statistik dapat disimpulkan bahwa besarannya nilai tambah yang diperoleh dari usaha pengolahan nenas menjadi selai nenas, dodol nenas dan pengolahan nenas menjadi nenas goreng terdapat perbedaan. Serta besarnya nilai tambah yang dihasilkan dari pengolahan produk nenas goreng pada setiap agroindustri memiliki perbedaan.

\section{UCAPAN TERIMA KASIH}

Pada kesempatan ini penulis menyampaikan ucapan terima kasih kepada Dekan Fakultas Pertanian Universitas Jambi dan Ketua Jurusan Agribisnis Fakultas Pertanian Universitas Jambi yang telah memfasilitasi dalam penelitian ini. Selain itu ucapan terima kasih juga diucapkan untuk semua pihak yang telah membantu dalam penelitian ini.

\section{DAFTAR PUSTAKA}

Aziz, M. Amin, dkk. 1993. Agroindustri Buah-Buahan Tropis. Dalam Lokakarya Strategi Operasional Investasi dan Perdagangan Subsektor Agroindustri dalam era Globalisasi.

Bangkit : PT. Insanmitra Satyamandiri, Jakarta.

Soeharjono, 2001. Konsep dan Ruang Lingkup Agroindustri. Kumpulan Makalah Agribisnis Jurusan Sosial Ekonomi Pertanian IPB, Bogor.

Soekartawi. 2000. Pengantar Agroindustri. PT. Raja Grapindo Persada, Jakarta.

Sudiyono A. 2004. Pemasaran Pertanian. UMM Press. Malang.

Suprapto. 2006. Proses Pengolahan dan Nilai Tambah. Penebar Swadaya. Jakarta.

Teguh, M. 2010. Ekonomi Industri. PT. Raja Grafindo Persada : Jakarta.

Wulandari, RR. 2015. Analisis Komparasi Nilai Tambah Produk Pada Agroindustri Keripik Pisang (Studi Kasus Pada Agroindustri Keripik Pisang"xxx" Di kabupaten Tanjung jabung Barat). Skripsi. Fakultas Pertanian. Universitas Jambi, Jambi. (Tidak dipublikasikan). 